A WORRIRG YODEL OF MORETON ISLAND PRBHISTORY: YRAP STAGB I

J. HALL and

Anthropology \& Sociology

University of Bueensland

\author{
RICHARD ROBINS \\ Australian Environnental Sciences \\ Griffith University
}

\title{
INTRODUCTION
}

The Moreton Region Archaeological Project (MRAP) was conceived in mid-1977 through a union of a lecturer new to Australia (HJH), a corpus of archaeological and historical information about the Brisbane area, and a small band of keen University of Queensland undergraduate archaeology students who had been meeting informally as a discussion group for the previous year. However, it was not until 1979 when MRAP received a generous input of funds from A.R.G.S. that the project really got off the ground. At this early stage, MRAP's aims were broad and general and not tied to any particular issue of inquiry in Australian archaeology. Essentially MRAP sought to characterise the archaeological record of the Moreton Region via the employment of systematic survey and excavation within three areal units: the subcoastal zone, the coastal strip, and the offshore islands (see Hall 1980a). This paper interprets the results of our investigations of the Moreton Island Component of the Offshore Islands Unit of MRAP - Stage I, and offers a working model of human settlement and subsistence.

\section{MORETON ISLAND}

Moreton Island is a wedge-shaped sand mass some $40 \mathrm{~km}$ northeast of Brisbane at between $27^{\circ} 01^{\circ}$ and $27^{\circ} 22^{\circ} \mathrm{s}$. Latitude and between $153^{\circ} 22^{\circ}$ and $153^{\circ} 28^{\circ}$ Longitude. Together with North and South Stradbroke Islands it forms the eastern boundary of Moreton Bay (Figure 1). It is some $34 \mathrm{~km} 10 \mathrm{ng}, 11 \mathrm{~km}$ wide at its widest point and is about $185 \mathrm{~km}^{2}$ in area. The island's origins and subsequent development are complex and a matter of debate (see Robins 1983:24); however, suffice it to say that, except for a rocky headland at its northeastern tip, it is a sand mass derived from Pleistocene and Holocene dune formation. In fact, Mt. Tempest and Storm Mountain are among the highest dunes in the world (Turner and Coaldrake 1976). It has a Wallum flora (Coaldrake 1961, Palmer and Coaldrake 1976) and a depauperate terrestrial fauna (Barry and Lear 1976). For further details concerning the island's environment the reader is referred to Heath and Partners (1976) and Robins (1983). 


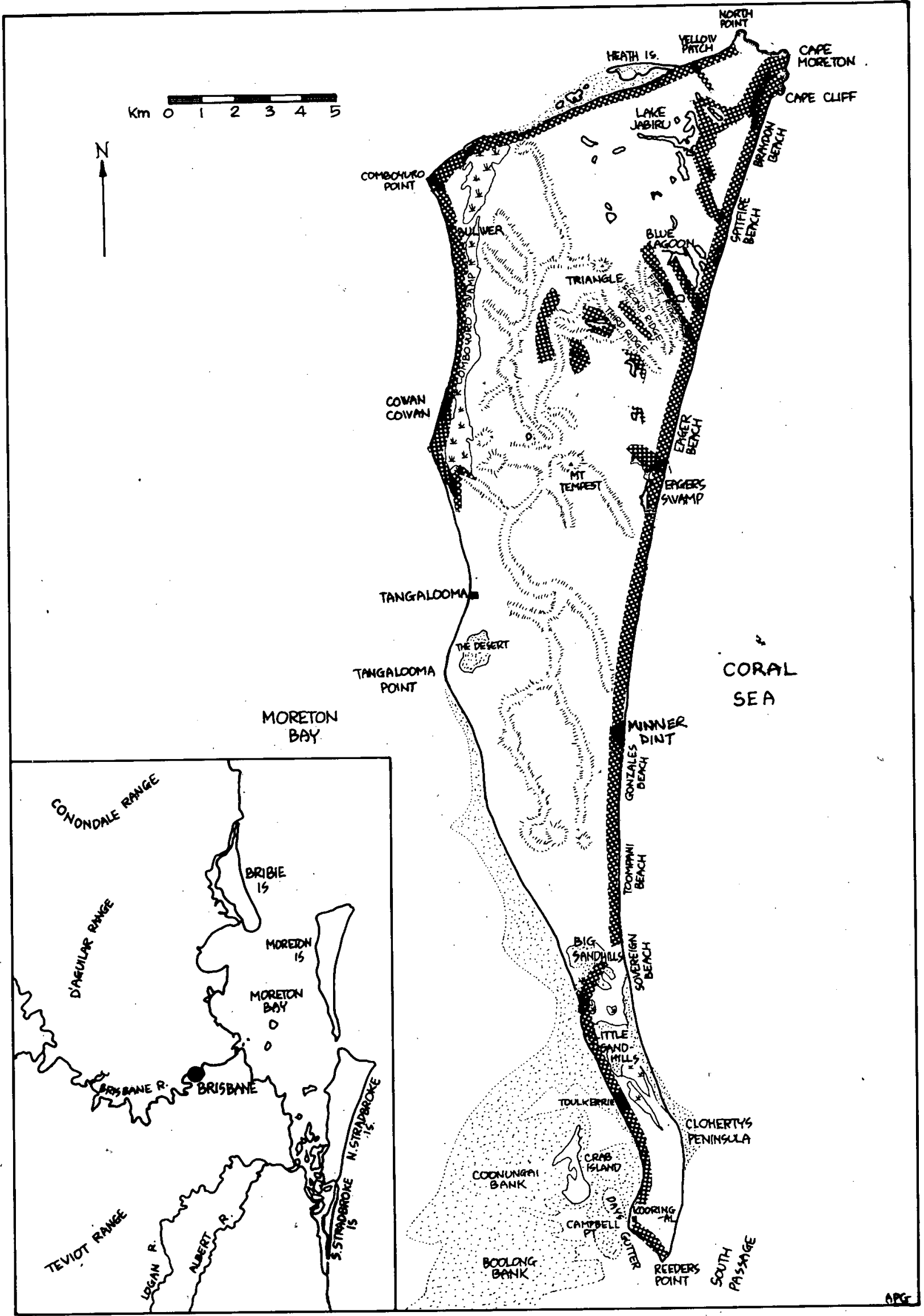

Figure 1. Map of Moreton Island showing localities mentioned in text. Shaded area represents pattern of site location - settlement. 


\section{SETTING THE STAGE}

Before discussing the archaeological results it is useful to place Moreton Island within the wider context of paleo-Australians and their changing Pleistocene-Holocene environment. "We propose to do this by making one or two assumptions about human colonisation in Australia and then offering an hypothetical but general sequential model of human adjustments to changing environmental conditions in Moreton Bay.

The dating of the Upper $S$ wan site at ca. 38,000 b.p. (Pearce and Barbetti 1981), the tail end of the radiocarbon dating scale, implies a human antiquity greater than 40,000 years and perhaps in the vicinity of 50-70,000 years (White and $0^{\prime}$ Connel1 1982:42). We do not take part in the colonisation debate but simply begin with an assumption which places humans effectively throughout the continent by 20-25,000 B.P. In the Moreton Region context we envisage people on the east coast as well as in the interior with the former perhaps living in higher densities than the latter, though not as high as estimated historically for Moreton Bay (Hal1 1982:84).

Between about 20,000 and $6,500-6,000$ B.P. (Flood 1981, 1984), melting Pleistocene ice caused inundation of a ca. $30 \mathrm{~km} s t r i p$ of land off the east coast of modern Moreton Island, the latest of at least four such transgressions to have occurred in the Pleistocene. (Relly and Baker 1984). The rate of this process was probably not uniform. Nevertheless, inundation may be roughly estimated at $2 \mathrm{~m}$ (horizontal) per year. Thus, we argue for a gradual adjustment model for human populations affected by this change. This model is contrary to that which might be called the "tribal displacement" kind which implies almost a human stampede away from the onrushing tide (eg. Blainey 1975). A1though coastal peoples were shifted ever landward, the fact that the entire process took some 14,000 years suggests to us that the effect upon economy, social organisation and the like may have been less dramatic.

The scenario presented is one of gradual adjustments by the paleoAustralian populations at both intra and inter-group levels from coast to hinterland. Drowning of the Brisbane River valley continued upriver until the dunes that are now Moreton and Stradbroke Islands represented a peninsula forming the eastern boundary of early Moreton Bay. When the sea level came to a relative standstill some 6,500 to 6,000 years ago at ca.1.0-1.5m higher than present (Flood 1984,. Relly and Baker 1984), Moreton Bay was fully formed, the peninsula now two islands. People continued to live much as they had done for the previous millenia with reference to subsistence and technology - exploiting the sea and a coastal strip. For 2,000 years, the bay experienced good ocean circulation with extensive coral growth, but at some time after ca. 4,000 B.P. the sea fell to its present level (Kelly and Baker 1984:164), after which, in turn, the tidal mudflat-mangrove communities with their potentially bountiful human food harvests built up.

We support the notion that it was only after this development to more estuarine bay conditions at perhaps 3,000 B.P. that the population of Moreton Bay began to reach the kinds of densities witnessed during European contact times (see Hall 1982; see also Hughes and Lampert 1982 for population argument). Despite minor fluctuations in sea level since then (Flood 1984), it is our opinion that the Moreton Bay environment, and especially that of Moreton Island, has not significantly altered. In this connection it should be noted that being a Wallum environment, it is naturally an ever-shifting mosaic of sand dunes, forests, swamps, heath, lakes and creeks (Coaldrake 1961). 
Moreton Island was thus transformed by rising seas from a "Moreton Hi11" (apologies to Sandra Bowdler 1979) - or at least a peninsula in the latter stages of the transgression - the west coast of which overlooked the ancient Brisbane River valley (Jones et al 1977:8).

At about this time some of the terrestrial, vertebrate food resources such as macropods may have been overhunted by humans and/or fallen prey to biogeographical processess common to islands. Certainly Moreton Island supports no large native terrestrial mammal populations today; Macropods and Dasyurids are conspicuousiy absent (Barry and Lear 1976). If such was the case, then humans may have had to make a significant economic adjustment to the change. This could have taken the form of an intensification of production in the direction of marine resources, plant foods or both. People may even have abandoned the island(s) for the mainland, not to return for centuries, perhaps millenia. Alternatively, they may have returned to periodically exploit them from the mainland throughout the Holocene.

Whichever the case(s), we considered that systematic archaeological investigation could supply evidence to test implications arising from the above and would thus allow an eventual understanding of the effects of the post-Pleistocene transgression upon hunter-gatherer populations of the region.

Initial archaeological work (MRAP -, Stage I) on Moreton Island sought to answer quite general and basic questions. First, we had to establish whether or not there was an archaeological record adequate to the task of supplying information to the above scenario. We knew that there were sites on Moreton Is land because two surveys had been conducted there previously (Ponosov n.d., Morwood 1975). While both had recorded, an abundance of sites, especially shell middens, neither had covered the entire island in a systematic and comprehensive manner sufficient to the aims of MRAP. Thus, a two-pronged enquiry was initiated which included a ca.20\% simple random sample survey and exploratory excavation of a small number of sites selected during an initial reconnaissance of the island. The results of the survey are presented by Robins ( $1983,1984 \mathrm{a}$ - this volume) and the excavation reports by Ha11 (1980b, 1984 -this volume) and Robins (1983,1984b -this volume). For substantive information and details about this fieldwork, the reader is referred to these works.

\section{THE FACTS AND A LATER MODEL. ,}

If people lived on Moreton Island prior to ca. 2,000 years ago, the archaeological record has yet to reveal their presence. While sites dating back over 5,000 years have been found in the Subcoastal zone of the Moreton Region, coastal or island sites have yet to demonstrably predate 2,000 b.p. (Alfredson 1983, Hall 1982, Kel1y, 1982). Irrespective of whether or not people lived on "Moreton Hill" prior to 6,500 B.P., available evidence indicates a human presence there only late in the Holocene, long after it had become an island. We do not suggest that people were not.there in earlier times; simply that any evidence for such is so far lacking. Once a systematically derived set of dates and more precise geomorphic developmental models for the island are to hand, we feel that clarification of this position will be possible. Nevertheless, on present evidence the archaeological record falls within the late Holocene. 
- In short, the evidence supports the argument above that people abandoned Moreton.Island after the post-Pleistocene transgression formed it, not to return for about 4,000 years. What follows is a working model of the settlement-subsistence regime on Moreton island during the past two millenia or so.

\section{Subsistence}

Early in our research we reasoned that if a population was to have maintained itself on this is land, the bulk of its protein would have come from the sea, more especially the littoral. Given the is land's present depauperate terrestrial faunal picture (Barry and Lear 1976), we were left little choice in this matter. However, we considered that archaeological work would help indicate just how long this had obtained and allow us to modify our thoughts appropriately. We also 8 tressed that plant foods would have been a very important part of the diet. This notion originated in our reading of historical records of Aboriginal life around Moreton Bay (eg. Petrie 1904, see also Draper 1978 and 1982 for a compilation of historical subsistence records). The most important among the many plant foods was the rhyzome of the fern Blechnum indicum, called by the Aborigines "Bungwall" (eg.Backhouse 1967, Eipper 1841 in Steele 1975:285, Petrie 1904). On the is lands this plant was ground into flour and baked into a kind of damper (Colliver and Woolston 1975). A seasonally important plant food was the berry called "Midyim". (Austromyrtus tenuifolia). During March-May it was the cause for gatherings of groups from other parts of the bay. Recent botanical investigations indicate at least 63 edible plant species on Moreton Island (Robins and Buhmann, in press).

Archaeological survey and excavation both point strongly to a marine-littoral subsistence orientation throughout the is land. Most sites contain an abundance of shellfish remains, many yield evidence of fish, some dugong and turtle. In contrast, few terrestrial animal remains have been recovered. As no site has yielded macropod bones, we infer that these animals have been absent from the island for at least 1500 years or so. A further inference is that the two islands, Moreton and Stradbroke, have been separated for this length of time.

The dugong bone is interesting in that it appears quite late in the archaeological record. Dugong were reported in their thousands by early European settlers in Moreton Bay. ( eg. Fred Campbel1 1891 in Thomson 1967:105). In fact they were so populous that a factory to render them down into oil, bacon and beef was established on Stradbroke Is land early in this century (Bel1 1984:13). They were much prized by the local Aborigines. Their quite late (the past few hundred years) entry into the archaeological record on leads us to speculate that they may be fairly recent migrants into the bay. Certainly their bones are massive enough that differential preservation could not be held accountable for their absence in sites. Since they require seagrass for fodder, that absence may be 1 inked to the development of seagrass communities in the bay. More excavation coupled with geomorphic data should elucidate this picture. At present then, the main animal remains comprise shellfish and fish.

Occasional1y, sites indicate exploitation of assumed plant foods (eg. Pandanus at Toulkerrie [Ha11 1984-this volume] and Minner Dint [Ha11 1980b]). However, the paucity of such is considered more a reflection of differential preservation than reality. Bungwall, being 
essentially starch, would not be expected to survive very long in the soil unless carbonised - likewise soft tissue of most other plants. The pandanus has survived due to carbonisation and its robustness. Thus, for reconstruction of plant foods we must turn to secondary evidence such as artefacts which can be demonstrated through usewear analys is to be associated with particular plant processing. Studies are presently underway to determine Bungwall use through analysis of stone artefacts (Ramminga 1981, Gillieson and Hall 1982).

In sum, the sites so far excavated and observed via intensive survey, have revealed assumed dietary remains which permits only one explanation - subsistence on Moreton Island was littorally and marine based. However, when one considers just where the sites are located, one can argue for more land-based food resources than are present in the sites.

\section{Settlement}

Research has demonstrated that sites are not evenly distributed over the is land (Robins 1983). Rather, sites tend to conform to the distribution of food and fresh water, other resources and optimal camping sites (flat; open and sheltered space) as these vary according to the three main physiographic divisions of the is land (Durrington 1977) (see shaded area in Figure 1). In the northern section of the Island occupation concentrated around the coastline in open woodland or forest areas in close proximity to swamps or creeks. Importantly, this same association was found in the interior of the northern section. Most inland sites consisted of small piles of shell, of both estuarine and open beach origin. We think these represent short-term base camps used when people went foraging for plant foods, honey, and small game. Sedimentary and volcanic stone from Cape Moreton provided the only island-based raw material source for flaked and ground stone artefacts. Thus, the north was economically very important in this respect. The fact that this material can be found in sites throughout the is land argues for either a great deal of trade or much movement of people. We argue for the latter based upon both the nature of the archaeological record. However, there is a need to undertake a sophisticated spatial analysis of the island's stone industry to test this notion.

There is little archaeological evidence for the use of the central section of the island outside of a narrow (ca. $500 \mathrm{~m}) \mathrm{strip}$ along the east coast (Figure 1). Within this strip a broad range of plant foods, marine and littoral resources, water and shelter were available. In marked contrast, only a limited number of plant and marine resources could be exploited from the west coast while the centre lacks water, exhibits a narrow range of foods, and has few suitable camping areas. We think this strip was probably used as a "highway" between the richer northern and southern areas, the base camps being fairly short-term. Most of the sites recorded in this section tended to comprise small thin bands of shell, only a few associated with stone artefacts. Even the larger, more complex sites contain evidence of sporadic occupation. For example, Minner Dint (Ha11 1980b) consisted of some 15 fairly small.and discrete interfingered layers of shell midden and dune sands. Pandanus and pipis and fish predominated among the assumed food remains.

In the low swampy southern section, archaeological evidence suggests that occupation tended to concentrate on the western side and southern end of the island in areas of open woodland and forest adjacent to what is now, and was at least in the recent past, an extensive 
estuarine environment. A variety of plant foods also grow in this area including the seasonally important berry "midyim" and the year-1ong potential staple "bungwall". We postulate that this area was of considerable economic importance and may have supported large (25-50 people) populations for extended periods of time. The northwestern side of the southern section was linked with the southern part of the central eastern section by a series of small campsites located in open woodland and forest beside small swamps and depressions. The east coast of the southern section was exposed, offered few resources and consequently was not much used for settlement. It should be noted however that this sector has undergone appreciable coastal erosion in this century at least, and thus may once have contained archaeological evidence.

In sum, the $20 \%$ systematic survey results coupled with excavation evidence indicates that sites are often located in such a way as to allow an optimisation of both land and sea exploitation (see Robins 1983). However, site location inferences rest on the assumption that all sites found are roughly contemporaneous. Now that dates spanning some 1500 years have been obtained, we are able to show that the location and the site contents have changed little over this period. Admittedly, a larger sample of dates and excavations is required before such a scenario may be presented with confidence. At present the archaeological evidence indicates that the above pattern of settlement and subsistence continued for approximatly 2000-1500 years with both small temporary inland camps and large permanent camps providing both old and recent dates.

Some evidence of the seasonal use of resources was recovered from excavations but our present opinion holds that season was less important an influence upon settlement than other factors such as resource depletion, weather, social obligations and the like. We are hopefull that ongoing and planned investigations will provide a finer resolution to this question.

\section{CONCLUSION}

The Pleistocene-Holocene human adjustment model presented in the first part of this paper has yet to be upheld or refuted. The reason is simply that no archaeological record has yet been established in the vicinity for this time period. Nevertheless, we find it a useful framework within which to conduct further investigation. Archaeological work so far has indicated no human presence on Moreton Island until the past two millenia; no site predates 1,600 B.P. From this, and corroborative evidence from other islands in Moreton Bay and Fraser Island, we infer that people left these localities when the bay was formed some 6,500 years ago, not to return for some 4,000 years. We reason on the basis of the current ecological picture in Moreton Bay, coupled with results of sea-level research, that this move to settle the islands was made possible by a late Holocene development of very rich littoral resources. It was probably gradual, beginning as short visits and ending as permanent residence. It perhaps also was influenced by interrelated social and demographic factors; however, that line of inquiry must await further theoretical and methodological development.

This late Holocene scenario has a number of consequences, most of which, one way or another are archaeologically testable. Stage II of MRAP, due to begin in 1985, will seek to test and refine the model for the Moreton Region generally as well as more specifically for Moreton Is land. 
ACKNOWLEDGEMENTS

We wish to especially thank all those Queensland University archaeology students and others who willingly, and in all weather, aided us in the Moreton Island research. To thank you all by name would be to add pages to this paper. Funding came from A.R.G.S and from the Department of Anthropology and Sociology, The University of Queensland.

\section{REFERENCES}

Alfredson, G. 1983 St. Helena Island: A Changing Patternof Exploitation? Australian Archaeology 17:79-86.

Backhouse, J. 1967 A Narrative of a Visit to the Australian Colonies. London: Hamilton, Adams and Co.

Bancroft, T. L. 1894 Note on Bungwall (Blechnum serrulatum, Rich.), An Aboriginal Food. Proceedings of the Linnean Society of New South Hales $19: 25-26$.

Barry, D.H. and R.J. Lear 1976 The Vertebrate Fauna of Moreton Is land. In A.A. Heath \& Partners Pty. Ltd.; Moreton. Island: Environmental Impact Study and Strategic Plan, pp.(2):72-82. Brisbane

Be11, J. P. 1984 Moreton Bay and How to Fathom it. Brisbane: Queens land Newspapers P.ty. Ltd.

Blainey, G. 1975 Triumph of the Nomads: A History of Ancient Australia. Melbourne: Macmillan.

Bowdler, S. 1979 Hunter Hill, Hunter Island. Unpublished Ph.D. thesis, Australian National University:

Coaldrake, J..E. 1961 The Ecosystem of the Coastal Lowlands ("Wallum") of Southern Queensland. CSIRO Bulletin 283.

Colliver, F. S. and F. P. Woolston 1975 The Aborigines, of Stradbroke Is land. Proceedings of the Royal Society of Queensland 86(16): .91-104, p1s.7-8.

Draper, N. 1978. A Model of Aboriginal Subsistence and Settlement in the Moreton Bay Region of Southeast Queensland. Unpublished B.A. (Honours) thesis, University of Queensland.

Draper, N. 1982 Food Resources of the Moreton Bay Aborigines. Occasion al Papers in Anthropology 10:124-147. Anthropology Museum, University of Queensland.

Durrington, L. R. 1977 Vegetation of Moretion Is land. Technical Bulletin No.1. Botany Branch, Department of Primary Industries, Brisbane.

Flood, P. G. 1981 Carbon-14 Dates from the Coastal Plains of Deception Bay, Southeastern Queens land.Queensland Government Mining Journa1 82:19-23. 
Flood, P. G. 1984 A Review of Holocene Sea Level Data, Southeastern Queensland. In R. J. Coleman, J. Covacevich and P. Davie (eds.), Focus on Stradbroke. pp.127-131. Brisbane: Boolarong Publications.

Gillieson, D. S. and J. Hall 1982. Bevelling Bungwall Bashers: A Usewear Study from Southeast Queensland. Australian Archaeology $14: 43-61$.

Hal1, H. J. 1980a Archaeology at the University of Queensland: A Brief Out line. Australian Archaeology 10:79-85.

Ha11, H. J. 1980b Minner Dint: A Recent Aboriginal Midden on Moreton Island. Occasional Papers in Anthropology 10:94-112. Anthropology Museum, University of Queensland.

Ha11, H. J. 1982 Sitting on the. Crop of the Bay: An Historical and Archaeological Sketch of Aboriginal Settlement and Subsistence in Moreton bay, Southeast Queensland. In S. Bowdler (ed.), Coastal Archaeology in Eastern Australia pp. 79-95, Prehistory Department, R.S.Pac.S., Australian National University.

Heath, A. A. and Partners Pty. Ltd. 1976 Moreton Island: Environmental Study and Strategic Plan. Brisbane: A.A.Heath and Partners Pty Ltd.

Hughes, P. J. and R. J. Lampert 1982 Prehistoric Population Change in Southern Coastal New South Wales. In S. Bowdler (ed.), Coastal Archaeology in Eastern Australia, pp.16-28, Prehistory Department, R.S.Pac.S., Australian National University.

Jones, M, H. Hekel and D. E. Searle 1977 Late Quatemary Sedimentation in Moreton Bay. Department of Geology, University of Queensland Papers 8(2):6-17.

Kamminga, J. 1981 The Bevelled Pounder: An Aboriginal Stone Tool Type from Southeastern Queensland. Proceedings of the Royal Society of Queensland 92:31-35, p1s.2-3.

Kelly, M. 1982 A Practical Reference Source to Radiocarbon Dates obtained from Archaeological Sites in Queensland. CRM Monograph Series No.4. Brisbane: Archaeology Branch.

Kelly, R. A. and J. Baker 1984 Geological Development of North and South Stradbroke Is lands and Surrounds. In R. J. Coleman, J. Covacevich and P. Davie (eds.), Focus_on Stradbroke. pp.156-66. Brisbane: Boolarong Publications.

Morwood, M. J. 1975 Moreton Island Archaeological Survey. Ms., Archaeology Branch, Department of Community Services, Queensland.

Palmer, J. W. and J. E. Coaldrake 1976 Terrestrial Vegetation of Moreton Is land. In, A.A. Heath and Partners Pty. Ltd., Moreton Is land: Environmental Impact Study and Strategic Plan. Pp.(2): $31-42$ 
Pearce, R. H. and M. Barbetti 1981 A 38,000-year-old Archaeological site at Upper Swan, Western Australia. Archaeology in Oceania $16(3): 173-178$.

Ponosov, V. V. n.d. Results of an Archaeological Survey of the Southern Region of Moreton Bay and of Moreton is land (196364). Ms., Department of Psychology, University of Queensland.

Robins, R. P. 1983 This Widow Land: Evaluation of Public Archaeology in Queensland Using Moreton Island as a Case Study. Unpublished M.A. thesis, The University of Queensland.

Robins, R. P. 1984a A Preliminary Archaeological Survey of Moreton Is land. Queensland Archaeological Research 1:33-50.

Robins, R. P. 1984b Three Archaeological Excavations on Moreton Is1and: First Ridge and the Little Sandhills. Queensland Archaeologica1 Research 1:51-60

Robins, R. P. and J. Buhmann (in press) Plantfoods of Moreton Is land. Queensland Archaeological Research 2. (ms.accepted Sept. 1984)

Steele, J. G. $1975^{\circ}$ Brisbane Town in Convict Days 1824-1842. Brisbane: University of Queensland Press.

Thomson, A. K. (ed.), 1967 The Collected Works of Thomas Welsby Vol.1. Brisbane: Jacaranda Press.

Turner, T. L. and. J. E. Coaldrake 1976 Region Geology. In, A.A. Heath and Partners Pty. Ltd., Moreton Island: Environmenta1 Impact Study and Strategic P1an, pp. (2):7-8.

White, J. P. and J. F, O'Connell 1982 A Prehistory of Australia, New Guinea and Sahul. North Ryde: Academic Press. 